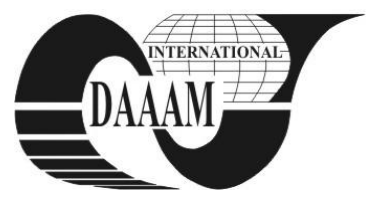

Annals of DAAAM for 2011 \& Proceedings of the 22nd International DAAAM Symposium, Volume 22, No. 1, ISSN 1726-9679 ISBN 978-3-901509-83-4, Editor B. Katalinic, Published by DAAAM International, Vienna, Austria, EU, 2011 Make Harmony between Technology and Nature, and Your Mind will Fly Free as a Bird Annals \& Proceedings of DAAAM International 2011

\title{
APPLICATION OF THE PROCESS APPROACH IN THE SHIPBUILDING INDUSTRY OF CROATIA
}

\author{
MIKACIC, I[vana] \& DULCIC, Z[elimir]
}

\begin{abstract}
Today's standard Croatian shipyards are faced with major problems of the globalized shipbuilding market, whose main feature is an exceptional competition with great cost pressures. Therefore, this paper aims to explore a new model based on the application of the process approach in modern shipyards, as one of the possible answers to these market demands. Business processes represent a key role in forming the optimal organization of modern enterprises. In this paper we propose application of the process approach in the shipbuilding industry of Croatia, as the first step to achieve profitability, to define the forms of ownership and to achieve rationalization of operations, in order for shipbuilding to become the major foundation for the development of Croatian economy.
\end{abstract}

Key words: global market, competition, process approach, shipbuilding industry, organization.

\section{INTRODUCTION}

Shipbuilding in Croatia is an important industry with long tradition and is generally export - oriented. Shipbuilding affects not only the country's balance of trade and employment, but also the entire economy. For manufacturing and equipping the ship, a few hundred to several thousand different materials, parts, equipment, etc. are needed, all of which could possibly be produced in the local factories and crafts. The main problem of the Croatian shipyards refers to international competitiveness, which should be reached due to the natural potential which they have, and the quality of ships.

The basic research target of this paper is to analyze the impact of process approach on the productivity. Business processes can be described as series of logically related activities that use resources of the company, its main goal being satisfying customers' needs for products or services of adequate quality in an adequate period of time, while simultaneously achieving some value (Grover; Jeong; Kettinger \& Teng, 1995). In terms of global market competition, enterprises can achieve a competitive advantage only by offering cheaper and better quality products and services, but effective and innovative business processes are what is required for the realization of such goals. Observation of the company through the process provides the authentic image of business. Therefore, it is important to monitor business processes and predict and manage their dynamic changes, all in accordance to gaining greater efficiency and better quality of either products or services. By simulating a business process, dynamics and behavior of the process are being analyzed in a variety of default conditions, especially when many intertwined parallelisms are present in their performance. A business model can be used for easier introduction of ISO certification and is an excellent base for computerization of business, whether by buying or developing solutions. In the case when business model is developed, IT solutions that are to be applied here are all in function of enabling efficient operations. Individual processes rarely occur alone. Outputs from one process usually present inputs to the next process (Harrington, 1991).

According to their features, shipyards are included in very complex business and manufacturing systems. This complexity is the result of the complexity of the final products - the vessels, the individual products with high capital values, being of different types and sizes. Such a complex product entails an equally complex process of shipbuilding, which requires a unique and special organizational structure of shipyards. Since shipyards simultaneously perform the activities on several locations, dealing with the various stages of construction or preparation for construction, a complex matrix - project organizational structure is the dominated one.

\section{PROCESS ORGANIZATION \\ APPROACH OF MANUFACTURING SYSTEMS \\ IN THE BUSINESS-}

The process orientation is the fundamental change in the perception of the organization and represents a decisive shift away from traditional vertical - hierarchical view of the execution of tasks, in relation to the view that emphasizes the horizontal connections between functions (Feldman, 2000). Figure 1 shows the traditional view of the organization and contemporary business reality.

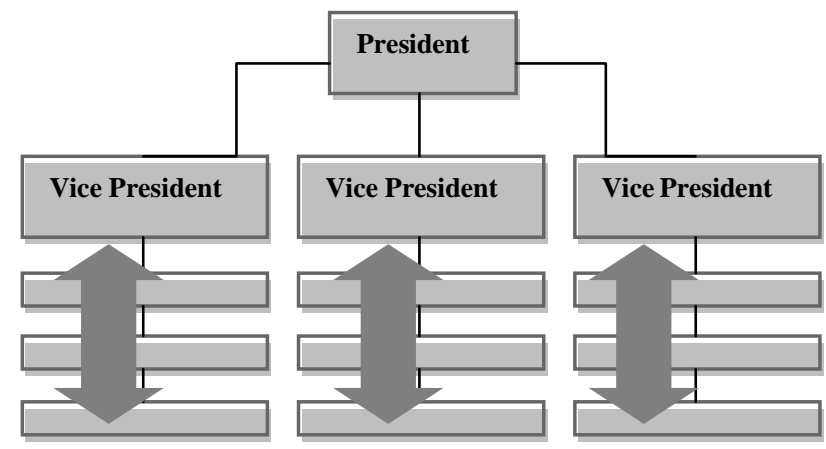

Functional organizational structure

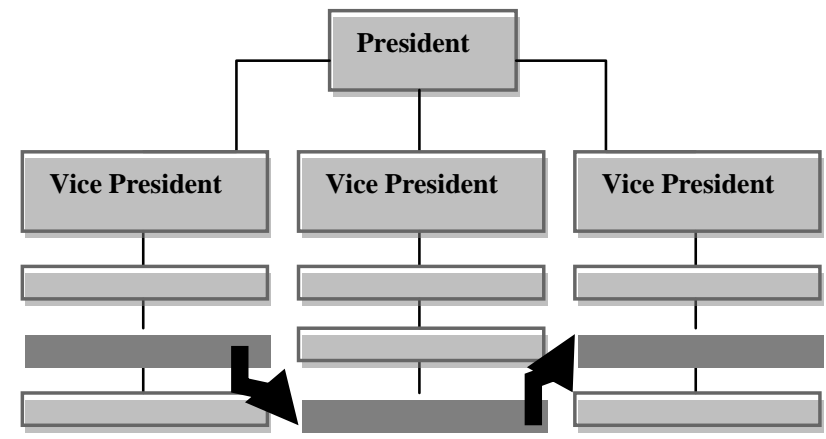

Organizational structure of the process

Fig. 1. The traditional view of the organization and contemporary business reality 
The difference between the functions and processes can be interpreted as the difference between whole and part (Mabert; Soni \& Venkataramanan, 2003).

The function here is a unit of work, the business activity that is usually performed by a group of people or even one person. The process, on the other hand, is a group of related tasks (functions) which together realize a specific value for a customer. One of the eight principles underlying the ISO 90002000 standard is applicable to the process approach. Standard 9000-2000 defines process as: "a set of interrelated or interdependent actions that transform inputs into outputs ", where inputs from one process are frequently outputs from other processes. The process must be assigned with the appropriate resources, so that it could happen. Figure 2 shows the basic elements of the process.

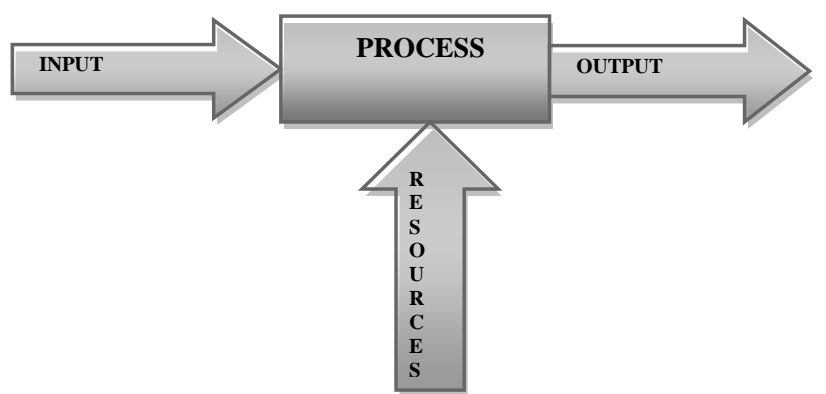

Fig. 2. The basic elements of the process

ISO 9001 emphasizes the importance of establishing the organization, implementation, management and continuous improvement of the effectiveness of the processes that are necessary for quality management system, and for managing the interaction of those processes to achieve organizational goals.

\section{APPLICATION OF THE PROCESS APPROACH IN SHIPBUILDING INDUSTRY}

At the first level, the whole process of shipbuilding is divided into the preparatory processes of the shipbuilding and of shipbuilding production processes.

By analyzing all of the shipbuilding processes at the third level and using the methods of classification and comparison of data, the only conclusion would be that one group of the processes extends to the entire shipbuilding process, the other group only to the preliminary part of the shipbuilding process, while the third group extends only to the manufacturing part of the Naval process.

Processes related to the entire shipbuilding process are: process development, process management, financial accounting process, the process of managing human resources, general administration process, and process assurance and quality control (QA / QC). The processes that are related only to the preparation of the shipbuilding process are: the sales process, process design, construction process, technological process, procurement process and process of storing rack material. The processes related to the production of the shipbuilding process are: relationships with partners process in manufacturing, steel processing, the process of composition of troops, the process of assembling troops, the process of letting the vessel into the water, the process of equipping the vessel, the process of corrosion protection, manufacturing processes, process support, process and maintenance of capital goods.

It can be concluded that on the third level of shipbuilding process there are three groups of processes: on the level of the entire shipbuilding process there are six processes, on the level of preparation of the shipbuilding process there are five processes and on the level of production of the shipbuilding process there are eight processes. These processes can be further subdivided into basic or key processes and to the supporting processes. Based on the analysis above, it can be concluded that the shipbuilding process at the third level consists of nineteen processes. These processes are furthermore, divided into a total of 91 sub-processes, which tells us about volumes, the size and the complexity of the shipbuilding process in general.

By analyzing the process and applying the process approach to the shipbuilding industry, the productivity of labor, the efficiency and profitability are increased. Transparent and properly lined business processes accelerate the company's work, help managing costs, and also contribute to the internal order and improvement of the quality of products / services. Ultimately they affect the overall organization, in such a way increasing business efficiency (Miles \& Snow, 1986).

\section{PLANNED ACTIVITIES}

The research described in this paper will lead to privatization of Croatian shipyards, where managers should improve the mechanisms for managing changes in the company, supported by an increased willingness for change.

The future research plan after applying the process approach is the implementation of e-business as the most important part of the business infrastructure.

The next step will be the distribution of knowledge which should be implemented at lower levels of the organization, shifting the transfer of responsibilities to each employee, which would also include measuring the success of individual employee.

\section{CONCLUSION}

This study is to analyze the impact of applying the model of process approach in the shipbuilding business, which wouldn't be possible without the simultaneous development and application of new technological advances in the methodology of construction of vessels. In addition, full implementation of production engineering is required.

The application of high technology in a larger part of the shipbuilding process would result in a time overlapping when it comes to constructing hull and outfitting the vessel.

Results of the transformation of Croatian shipyards applying the model of process approach show that using the new model opens up the possibility of increasing the business efficiency of shipyards, which is primarily, reflected in reduced number of employees and the increased production volumes.

In consequence, the productivity, as one of the most important elements of competitiveness and success of a shipyard, will significantly increase.

\section{REFERENCES}

Grover, V.; Jeong, S.R.; Kettinger, W.J. \& Teng J.T.C. (1995). The Implementation of Business Process Reengineering. Journal of Management Information Systems, Vol.12, No.1, pp. 109-114

Feldman, C. (2000). The Practical Guide to Business Process Reengineering Using IDEFO, Dorset House Publishing, ISBN O-932633-37-4, New York

Harrington, H. J. (1991). Business process improvement, McGraw - Hill, ISBN 0- 0702-6768- 5, New York. Mabert V. A.; Soni, A. \& Venkataramanan M. A. (2003)

Enterprise resource planning : Managing the implementation Process. European Journal of Operational Research, Vol. 146, No. 2, pp. 302-314

Miles, R.E. \& Snow, C.C. (1986).Organizations: new conceptsfor new forms, California Management Review, Vol.28, No.3, pp. 62-73 